\title{
Disinformation in Elections
}

\author{
Max Bader \\ University Lecturer, Leiden University \\ m.bader@hum.leidenuniv.nl
}

\begin{abstract}
In recent years there has been increasing attention to the potentially disruptive influence of disinformation on elections. The most common forms of disinformation in elections include the dissemination of 'fake news' in order to discredit opponents or to influence the voting process, the falsification or manipulation of polling data, and the use of fake election monitoring and observation. This article presents an overview of the phenomenon of disinformation in elections in both democratic and undemocratic environments, and discusses measures to reduce its scope and negative impact.
\end{abstract}

\section{Keywords}

elections - disinformation - OSCE - fake news - polling election observation

The ability of disinformation to influence the outcome of elections has been widely discussed in the aftermath of the Brexit referendum and the U.S. presidential elections in 2016. Beyond these pivotal votes, there is a growing realization that disinformation has become a major feature of elections in many countries around the world. With regard to disinformation in elections instigated by foreign actors, Russia is widely seen as the main culprit. ${ }^{1}$ Increasingly, however, there is evidence that the authorities of other states also employ disinformation to manipulate electoral processes abroad. ${ }^{2}$ And

1 E.g. T.C. Helmus et al., Russian Social Media Influence. Understanding Russian Propaganda in Eastern Europe, Rand Corporation, 2018; Atlantic Council Eurasia Center, The Kremlin's Trojan Horses, Atlantic Council, 2018.

2 E.g. Countering China's Sharp Power: Disinformation and Social Media in Taiwan, Sigur Center for Asian Studies Asia Report, 2019; S. Frenkel, K. Conger, K. Roose, Russia's Playbook for Social Media Disinformation Has Gone Global, New York Times, 31 January 2019.

(C) MAX BADER, 2019 | DOI:10.1163/18750230-02901006

This is an open access article distributed under the terms of the prevailing CC-BY-NC license at the time of publication 
while disinformation in elections is often associated with the phenomenon of 'fake news', other forms of disinformation including misleading polls and false claims by election monitors should also be regarded as important forms of disinformation in elections.

The growing impact of disinformation is among a range of reasons why democracies across the world are under pressure. It is now widely accepted that disinformation can have a significant impact on the outcome of an election. A group of researchers at the Berkman Klein Center at Harvard University have found, for instance, that coverage of the campaign for the 2016 U.S. presidential election on social media that was affected by disinformation largely followed Donald Trump's agenda. ${ }^{3}$ Similarly, researchers in a study about the use of bots on twitter during the Brexit campaign conclude that public opinions about Brexit were likely to be manipulated by those bots. ${ }^{4}$ Disinformation moreover can help undermine general trust in political systems that have been stable and successful for a long time. Aside from its corrosive impact on democracies, disinformation can also buttress authoritarian rule. The purpose of disinformation in competitive elections is different than in uncompetitive elections. While in competitive elections disinformation is employed to help a certain party or candidate or to delegitimize the existing political order, the main purpose of disinformation in uncompetitive elections, by contrast, is to convey the impression that the political order is legitimate.

This article presents an overview of the phenomenon of disinformation in elections in both democratic and undemocratic environments and discusses measures to reduce its scope and negative impact. Disinformation is commonly understood as knowingly false information (other than misinformation, which refers to unwittingly false information). ${ }^{5}$ In the context of elections, disinformation is usually about the dissemination of knowingly false information with the goal to undermine political opponents, to manipulate the voting process, or change perceptions of the political circumstances in which the election takes place. Disinformation is just one of many possible strategies that are employed to manipulate elections. Those other strategies include the

3 R.M. Faris, H. Roberts, B. Etling, N. Bourassa, E. Zuckerman, and Y. Benkler, Partisanship, Propaganda, and Disinformation: Online Media and the 2016 U.S. Presidential Election, Berkman Klein Center for Internet \& Society Research, 2017.

4 Y. Gorodnichenko, T. Pham and O. Talavera, Social network, sentiment and political outcomes: Evidence from \#Brexit, 2018. Retrieved 8 March 2019, https://www.nber.org/papers/ w24631.pdf.

5 E.g. C. Jack, Lexicon of Lies: Terms for Problematic Information, Data \& Society Research Institute, 2017 . 
micro-targeting of voters with ads, the hacking of e-mail accounts in order to discredit opponents, cyberattacks against election infrastructure, and support for anti-systemic forces by foreign governments. These strategies may be as harmful as disinformation and they have equally been the subject of much recent scrutiny, but they are not discussed here.

\section{1 Elections and Fake News}

The term "fake news" has been widely misused but, when properly defined, represents a key form of disinformation. A useful definition of fake news is "information that mimics news media content in form but not in organizational process or intent", with fake news outlets lacking "the news media's editorial norms and processes for ensuring the accuracy and credibility of information". ${ }^{6}$ In the context of elections, fake news becomes disinformation when it is presented or promoted to discredit opponents or to influence the voting process.

The frequency with which people encounter fake news, often without realizing it, is likely very substantial. It has been estimated, for instance, that one in four Americans visited a fake news website in the weeks leading up to the 2016 presidential elections. ${ }^{7}$ In the United Kingdom, a third of people admit to having been fooled by a fake news story at least once. ${ }^{8}$ Fake news stories can be created practically anywhere and by anyone. A number of fake news stories in the 2016 presidential elections in the United States, such as the story about the pope endorsing Donald Trump's candidacy, were created or promoted by a group of media amateurs operating from North Macedonia. Fake news is also created or promoted, however, by professional media organizations. Among such professional media organizations are hyper-partisan outlets like Breitbart whose commitment to pushing a certain political agenda is greater than their commitment to principles of journalism. Another type of professional media organization that spreads fake news are outlets, like the Russian 'news agencies' RT and Sputnik, that are controlled by governments. Through their network of television channels and websites broadcasting and publishing in a

6 D. Lazer et al., 'The science of fake news', in Science, 2018, no.6380, p.1094.

7 A. Guess, B. Nyhan, J. Reifler, Selective Exposure to Misinformation: Evidence from the consumption of fake news during the 2016 U.S. presidential campaign, 2018. Retrieved 7 March 2019, http://www.ask-force.org/web/Fundamentalists/Guess-Selective-Exposure-toMisinformation-Evidence-Presidential-Campaign-2018.pdf.

8 N. Bernal, 'Facebook approved fake Brexit ad 'paid for by Cambridge Analytica', in The Telegraph, 31 October 2018. 
range of languages, RT and Sputnik target audiences outside Russia. Broadcast media that are principally targeted at a domestic audience, however, can also play a role in spreading fake news in foreign countries. Russian state-controlled television channels that are watched by audiences in other post-Soviet states, for instance, likely have an effect on public opinion in those countries.

Disinformation only achieves its goal when it is widely spread. Among actors spreading fake news stories, a distinction is whether they do so intentionally or not. Most people who help to spread fake news stories are probably unaware that the relevant stories are fake news and in that sense act as the 'useful idiots' of those who created the fake news. A few months before the 2016 referendum in the Netherlands about the association agreement with Ukraine, for instance, a video was shared by a popular Dutch website in which people posing as Ukrainian nationalists burn a Dutch flag. When the story was picked up by a range of Dutch media, they were probably unaware that the story was fake.

The main actors who promote fake news deliberately are hyper-partisan media outlets such as the above-mentioned Breitbart in the United States, and trolls. Internet trolls are members of an online community who seek 'to disrupt, attack, offend or generally cause trouble within the community by posting certain comments, photos, videos, GIFs or some other form of online content.' ${ }^{9}$ In addition to just posting messages or comments, trolls, among other things, manipulate search algorithms and engage in spam campaigns through keyword stuffing, link bombs, and creating mutual admiration..$^{10}$ One type of troll promotes fake news at their own initiative. Often, these trolls are part of a larger community with different degrees of cohesion, such as the altright movement or conspiracy groups. ${ }^{11}$ Another type of troll is active as part

9 See https://www.lifewire.com/types-of-internet-trolls-3485894 (retrieved 9 April 2019).

10 Keyword stuffing is 'adding popular keywords to promote websites in search engine rankings'; link bmobs means 'using anchor text in links to relate specific search queries with required websites'; and creating mutual admiration societies refers to 'groups of websites with links pointing to each other', see J. Tucker et al., Social Media, Political Polarization, and Political Disinformation: A Review of the Scientific Literature, 2018. Retrieved 6 March 2019, https://eprints.lse.ac.uk/87402/1/Social-Media-Political-Polarization-andPolitical-Disinformation-Literature-Review.pdf, p.3o.

11 A. Marwick and R. Lewis, Media Manipulation and Disinformation Online, Data \& Society Research Institute, 2017; F. Morstatter et al. From alt-right to alt-rechts: Twitter analysis of the 2017 German federal election, 2018. Retrieved 6 March 2019, https://isi. edu/ fredmors/paperpdfs/arar-www-2018.pdf. 
of an effort that is coordinated, for example by a government. The use of trolls by the Russian government in particular has been extensively documented. ${ }^{12}$

Next to trolls, a major instrument in the intentional dissemination of fake news, including around elections, are bots. Bots are the primary form of computational propaganda, which has been defined as "the use of algorithms, automation, and human curation to purposefully distribute misleading information over social media networks". ${ }^{13}$ Relevant for the dissemination of fake news around elections are so-called 'political bots', which are user accounts that have "been equipped with the features or software to automate interaction with other user accounts about politics". ${ }^{14}$ An example of fake news spread by bots occurred during the campaign of the parliamentary elections in Armenia in 2017. According to the fake news story, the United States intended to sway the election by providing support to Armenia's opposition..$^{15}$ The scope of disinformation efforts in elections through the use of bots is impressive. In the weeks before the 2018 referendum in North Macedonia on whether to change the country's name, for example, there was a sudden and sharp increase in Twitter bot accounts commenting on the referendum. ${ }^{16}$ In the final month before the 2016 presidential elections in the United States, 400,00o bots posted about 3.8 million tweets. ${ }^{17}$ The impact of disinformation efforts using bots is hard to establish, but one group of researchers, for example, note that "our results suggest that the Brexit result is predictable through the social media, and public opinions about Brexit were likely to be manipulated by bots".18

12 E.g. D. Boffey, 'Europe's New Cold War Turns Digital as Vladimir Putin Expands Media Offensive', in The Guardian, 5 March 2016; N. MacFarquhar, 'Inside the Russian Troll Factory: Zombies and a Breakneck Pace', in The New York Times, 18 February 2018.

13 S. Woolley and P. Howard, Computational Propaganda Worldwide: Executive Summary, Computational Propaganda Research Project Working Paper no. 2017.11, 2017, p.3.

14 P. Howard, S. Woolley and R. Calo, 'Algorithms, bots, and political communication in the US 2016 election: The challenge of automated political communication for election law and administration', in Journal of Information Technology \& Politics, 2018, no.2, p.85.

15 Digital Forensic Research Lab, Fakes, Bots, and Blockings in Armenia A snapshot of online manipulation on the eve of a parliamentary vote, 2017. Retrieved 3 March 2019, https:// medium.com/dfrlab/fakes-bots-and-blockings-in-armenia-44a4c87ebc46.

16 M. Chertoff and A.F. Rasmussen, 'The Unhackable Election: What It Takes to Defend Democracy', in Foreign Affairs, 2019, no.98, pp. 158-9.

17 A. Bessi and E. Ferrara. 'Social bots distort the 2016 US Presidential election online discussion', in First Monday, 2016, no. 21.

18 Y. Gorodnichenko, T. Pham and O. Talavera, Social network, sentiment and political outcomes: Evidence from \#Brexit, 2018. Retrieved 8 March 2019, https://www.nber.org/ papers/w24631.pdf. 
Creating and operating bots is relatively easy. As with trolls, the use of bots by operatives of the Russian government has been widely documented. ${ }^{19}$ In addition, commercial parties sell bot accounts on a black market which also trades in likes, comments, and subscribers. ${ }^{20}$ Bot accounts are often used for a limited period and as part of a particular effort. Researchers have found, for instance, that bots that were used to promote alt-right narratives during the 2016 U.S. presidential elections, were subsequently used in the 2017 presidential election in France. ${ }^{21}$

Different types of measures have been proposed to counter fake news, in elections and beyond. One type of measure is to act against known channels of disinformation, even if at the risk of being accused of censorship. In 2016, for instance, the Latvian authorities shut down the Latvian domain of Sputnik. RT in the United Kingdom has been the subject of an investigation by Ofcom, the country's communications regulator, for breaking impartiality rules when covering the Salisbury attack. Social media platforms have taken tentative steps to contain disinformation. Facebook, for instance, has a mechanism in place allowing to flag fake news stories with a "Disputed by 3rd Party Factcheckers" tag. Twitter has blocked some accounts that have spread disinformation emanating from Russia. And Google has made it impossible for some fake news sites to earn money through Google's advertising network. ${ }^{22}$ Given the central role of social media in the dissemination of disinformation, the social media platforms are under pressure from political authorities to address the issue. The European Commission, in particular, has developed a Code of Practice on Disinformation in cooperation with social media platforms that commits them to taking action against disinformation.

'Softer' measures include efforts to raise awareness about disinformation and increase the resilience of its potential consumers. To increase resilience against disinformation, a report commissioned by the European Commission recommends, for example, to safeguard "the diversity and sustainability of the European news media ecosystem". ${ }^{23}$ The Ukrainian initiative StopFake and the

19 E.g. A. Badawy, K. Lerman and E. Ferrara, Who Falls for Online Political Manipulation? The case of the Russian Interference Campaign in the 2016 US Presidential Election, 2018. Retrieved 7 March 2019, https://arxiv.org/pdf/1808.03281.

20 NAto StratCom CoE, The Black Market for Social Media Manipulation, 2018. Retrieved 8 March 2019, https://www.stratcomcoe.org/download/file/fid/79968.

21 E. Ferrara, Disinformation and social bot operations in the run up to the 2017 French presidential election, 2017. Retrieved 8 March 2019, https://arxiv.org/pdf/1707.00086.

22 Lazer et al., op.cit., p.1096.

23 A multi-dimensional approach to disinformation. Report of the independent High level Group on fake news and online disinformation. European Commission, 2018. 
'EU versus Disinformation' campaign of the European External Action Service East Stratcom Task Force are examples of efforts that call out Russian disinformation and fact-check dubious claims in order to set the record straight. Experts on disinformation, however, argue that fact-checking of fake news may not be effective considering that fact-checks rarely reach those who have been fooled by it, and that people tend to recognize information as true even after they have been alerted that the information is false. ${ }^{24}$

\section{$2 \quad$ Disinformation in Polling}

A specific form of disinformation around elections concerns the falsification or manipulation of polling data. In the most extreme case, polling has not even been conducted, and data are conjured out of thin air. In Mexico, for instance, the forgery of polling data has become a widespread phenomenon and, disturbingly, established media outlets often report the 'results' of such polling data without blinking. ${ }^{25}$ In other cases, polling has been conducted, but with a clear slant. In the United States, for instance, the Rasmussen polling agency is openly supportive of Republican politicians and its polling data show a consistently higher approval rating for Trump than the polling data of most other polling agencies. While the Rasmussen polls exist amid the polls or more reputable agencies, in some countries all major agencies that conduct polling are influenced by partisan motivations, such as in Georgia ahead of the 2018 presidential elections. In one poll conducted shortly before the election, candidate Bakradze was at $30 \%$, while he was at only $5 \%$ according to a different poll (his eventual vote share was $11 \%$ ). Candidate Vashadze appeared as the clear frontrunner in one poll with $44 \%$ against $9 \%$ for his rival Zourabichvili (in the first round, Zourabichvili won with $39 \%$ of the vote against Vashadze's $38 \%) .{ }^{26}$ Partisan polling also extended to the exit-polls taken on the night of the election. According to one exit-poll, for example, Zourabichvili had supposedly won with $52 \%$ of the vote, which would have foregone the need for a second round, while Vashadze had received only $28 \% .{ }^{27}$

\footnotetext{
24 Lazer et al., op.cit., p.1095; Guess and Nyhan, op.cit.

25 J. Buendía, Fake Polls as Fake News: The Challenge for Mexico's Elections, Wilson Center, 2018.

26 See https://www.facebook.com/primariesinGeorgia/photos/a.1857173644533584/2100047 $856912827 /$ ?type $=3 \&$ source $=44$ (Retrieved 4 March 2019).

27 See http://rustavi2.ge/en/news/117324.
} 
Misleading polling data are often intended to change perceptions of what the outcome of the vote will be. The 'results' of a fake poll which were published right after a televised debate between candidates in the 2000 presidential elections in Mexico, for instance, were meant to create the impression that candidate Fox was the leading candidate. ${ }^{28}$ Misleading polls can also be used by candidates to claim victory when they have not actually won. Candidate Yanukovych, for instance, was able to point to exit-polls when he claimed victory in the 2004 presidential elections in Ukraine, even when more reputable polling agencies indicated that his rival Yushchenko had won the election. ${ }^{29}$

Countering misleading polls involves some of the same measures discussed in relation to countering fake news. In addition, to prevent misleading polls from gaining traction in the media and elsewhere, efforts should be undertaken to strengthen the capacity and reputation of professional polling agencies. In many countries, the publication of polling data is prohibited during one or several days before an election. The primary reason behind such bans is often to prevent polls from having an excessive impact on voting behavior. An additional reason for a polling silence period that authorities might consider, however, is that it specifically prevents voters from being influenced by false information about the preferences of other voters.

\section{Disinformation in Election Observation}

The monitoring of elections, including by international observers, has become a near-universal norm in recent decades. ${ }^{30}$ The norm, in fact, has become so strong that election observation is now common in many states with authoritarian governments which do not intend to hold competitive or fair elections. Election observation for authoritarian regimes can be inconvenient when observers release critical findings and as a result the public at home as well as the international community become better informed about the undemocratic nature of the regime. Authoritarian regimes can respond to the potential threat posed by election observation in different ways. One response has been to crack down on the work of independent domestic election watchdogs. In

\footnotetext{
28 Buendia, op.cit.

29 V. Paniotto, Ukraine: Presidential Elections 2004 and the Orange Revolution, 2004. Retrieved 8 November 2007, http://old.kiis.com.ua/pub/president\%2oelection\%2oin\%20 ukraine\%202004.pdf, p. 16.

30 J. Kelley, 'Assessing the complex evolution of norms: the rise of international election monitoring', in International Organization, 2008, no. 2.
} 
Russia, for instance, the foremost election watchdog Golos has been serially intimidated and harassed by the authorities. ${ }^{31}$ And in Azerbaijan, the Election Monitoring and Democracy Studies Centre has repeatedly been denied registration, and its leader Anar Mammadli has faced arrest and prosecution. ${ }^{32}$ With regard to international election observation, authoritarian governments have sometimes resorted to banning international observers under various pretexts. The OSCE, for instance, was unable to observe the 2007 parliamentary election in Russia because its experts and long-term observers were denied entry visas. ${ }^{33}$ Similarly, the OSCE was forced to cancel its mission to the 2015 parliamentary elections in Azerbaijan when that country's authorities put restrictions on the number of observers. ${ }^{34}$

Another common response to the threat of election observation has been to neutralize its potential negative impact by supplementing the existing range of observers with observers who are known to release findings that are favorable to the authorities. In the post-Soviet area, the appearance of such loyal monitors seems in part to be related to the 'color revolutions' which removed competitive authoritarian regimes in Georgia, Ukraine, and Kyrgyzstan between 2003 and $2005 .{ }^{35}$ The 'zombie monitors' engage in disinformation because they knowingly spread false information about the integrity of the voting process. In order to neutralize the critical statements of domestic election watchdogs, authoritarian governments often organize GONGOs (government-organized non-governmental organizations) to play the role of election monitors. One such GONGO, the Committee for Election Control, for instance, predictably declared that it had not found observed violations in the parliamentary elections in Kazakhstan in $2007 \cdot{ }^{36}$ Similarly, observers from the government-organized

31 E.g. G. Baczynska, Russia suspends vote monitoring group under 'foreign agent' law, 26 June 2013. Retrieved 7 March 2019, https://www.reuters.com/article/us-russia-ngos-golos/ russia-suspends-vote-monitoring-group-under-foreign-agent-law-idUSBRE95PoZV2013 0626.

32 Anar Mammadli, 23 April 2015. Retrieved 7 March 2019, https://www.esiweb.org/index .php?lang=en\&id=579.

33 osce/odihr, odihr unable to observe Russian Duma elections, 16 November 2007. Retrieved 8 March 2019, https://www.osce.org/odihr/elections/49175.

34 OSCE/ODIHR, Restrictions imposed by Azerbaijan compel cancellation of parliamentary election observation mission, says ODIHR Director Link, 11 September 2015. Retrieved 8 March 2019, https://www.osce.org/odihr/elections/azerbaijan/181611.

35 C. Walker and A. Cooley, 'Vote of the Living Dead', Foreign Affairs, $3_{1}$ October 2013. Retrieved 2 November 2013, https://foreignpolicy.com/2013/10/31/vote-of-the-living-dead/.

$36 \quad$ 'Komitet po kontrolyu za vyborami ne vyyavil grubykh narusheniy pri golosovanii', 19 August 2007. Retrieved 20 April 2010, https://www.kt.kz/rus/society/komitet_po_kontrol ju_za_viborami_ne_vijavil_grubih_narushenij_pri_golosovanii_1153422923.html. 
Public Chamber found that the 2018 presidential elections in Russia were held without violations. ${ }^{37}$ In order to neutralize the statements of professional international observers, authoritarian governments invite individual observers or observers from international organizations who are known to be loyal, or they set up new international election observation groups. During successive elections, for instance, the Kazakh government has secured positive statements about its elections from a range of regime-friendly foreign observers. ${ }^{38}$ While the OSCE/ODIHR mission concluded that the 2019 presidential election 'was tarnished by clear violations of fundamental freedoms as well as pressure on critical voices', ${ }^{39}$ an individual observer from Hungary was quoted by Kazakh media as saying that 'there have been no problems whatsoever. ${ }^{40}$ In the post-Soviet area, observers from the Commonwealth of Independent States, operating under the banner of CIS-EMO, have monitored most elections in the region since the mid-200os. In the authoritarian states where they observe an election, CIS-EMO monitors invariably release a positive and similarly formulated statement. After the 2017 presidential election in Turkmenistan, for instance, CIS-EMO released a statement that concluded that the elections "adhere to universally agreed international norm of democratic elections" and "were organized professionally and were transparent, open, free, and competitive". ${ }^{41}$ Politically biased international election observation seems to have first gained prominence in the post-Soviet area. However, in recent years, the phenomenon has increasingly spread to other countries, such as Cambodia and Zimbabwe. ${ }^{42}$

One way to counter the disinformation of 'zombie monitors' is to strengthen the norms and principles of professional election observation and by doing

37 See https://www.fontanka.ru/2018/03/19/007/ (retrieved 8 April 2019).

38 C. Michel, 'Western Whitewashing of Kazakhstan's Election', The Diplomat, 22 March 2016. Retrieved 7 March 2019, https://thediplomat.com/2016/o3/western-whitewashingof-kazakhstans-election/.

39 See https://www.osce.org/odihr/elections/kazakhstan/422510?download=true (retrieved 10 June 2019).

40 See https://inbusiness.kz/ru/news/chto-udivilo-mezhdunarodnyh-nablyudatelej-navy borah-v-kazahstane (retrieved 1o June 2019).

41 'Zayavlenie Missii Nablyudateley ot Sodruzhestva Nezavisimykh Gosudarstv po rezul'tatam nablyudeniya za podgotovkoy i provedeniem vyborov Prezidenta Turkmenistana, sostoyavshikhsya 12 fevralya 2017 goda'. Retrieved 7 March 2019, http://e-cis.info/ page.php?id=25892.

42 A. Shekhovtsev, The globalisation of Pro-Kremlin Networks of politically Biased Election observation: the cases of Cambodia and Zimbabwe, 22 November 2018. Retrieved 7 March 2019, https://www.epde.org/en/news/details/the-globalisation-of-pro-kremlin-networks -of-politically-biased-election-observation-the-cases-of-cambodia-and-zimbabwe-1686 .html. 
so expose the contrast between professional election observation and that of the 'zombie monitors'. In 2005, international election observation organizations, for instance, adopted the Declaration of Principles for International Election Observation and its Code of Conduct. The Declaration is currently endorsed by 55 organizations. The Global Network of Domestic Election Monitors (GNDEM), which unites 251 domestic election observation organizations, has taken a similar step in 2012 by adopting the Declaration of Global Principles for Nonpartisan Election Observation and Monitoring by Citizen Organizations. ${ }^{43}$

4

\section{Counteraction}

The disruptive impact of disinformation in elections is unlikely to diminish in the years to come. For governments and other actors that seek to legitimize undemocratic elections and delegitimize democratic elections or undermine specific candidates or parties, the use of disinformation is a low-cost strategy with a potentially high impact. Media landscapes are undergoing a transformation in which established media organizations gradually lose authority and their audience while social media continue to grow in importance. So long as social media platforms do not put into place extensive measures to proactively fight disinformation, or are forced to do so, those engaged in spreading in disinformation will find that the obstacles are few and the opportunities many. Disinformation in elections is especially noticeable in the forms of fake news that is disseminated to discredit opponents or to influence the voting process, the falsification or manipulation of polling data, and the corruption of election monitoring. As discussed above, there are different types of measures that are taken to fight these forms of disinformation. A comprehensive initiative to combat disinformation in elections is the Transatlantic Commission on Election Integrity, led by former NATO Secretary General Anders Fogh Rasmussen and U.S. Secretary of Homeland Security Michael Chertoff. ${ }^{44}$ The commission aims to address the issue of foreign interference in elections, among other things by conducting assessments of democracies with upcoming elections in order to identify vulnerabilities to foreign interference, including through disinformation. Founded in 2018, it is yet to be seen if the Transatlantic Commission on Election Integrity can become an effective instrument in the fight against disinformation in elections.

43 See https://gndem.org/declaration-of-global-principles/(retrieved 6 April 2019).

44 See http://www.allianceofdemocracies.org/initiatives/the-campaign/. 
What role can the OSCE play? The OSCE addresses the issue of disinformation primarily through its Representative on Freedom of the Media. According to the website of the Representative, "[d]isinformation, sometimes referred to as "false" or "fake news", and propaganda pose numerous threats to democratic societies" ${ }^{45}$ The Representative maintains a liberal position on the issue, arguing that blocking or banning media outlets is "not an answer to the phenomenon of disinformation and propaganda, as it leads to arbitrary and politically motivated actions". There is potential for the OSCE to increase its role in the fight against disinformation through its election observation missions. Each OSCE election observation mission contains a media analysis component and a political analysis component. ${ }^{46} \mathrm{~A}$ problem of the media analysis component in election observation missions is that it is based on a set of commitments that were agreed before the internet and social media become major factors in elections. The 2012 Handbook on Media Monitoring for Election Observation Missions, published by OSCE/ODIHR, does not mention 'disinformation', 'fake news', or even 'social media'. The media analysis therefore currently lacks the tools for a comprehensive analysis of election-related disinformation in the media. Other components of the observation missions, foremost the political analysis, may have greater potential to systematically address disinformation, including fake news and misleading polling, and this potential should be explored. OSCE/ODIHR election observation missions, given their considerable weight and authority, provide a powerful opportunity to increase knowledge and awareness of the impact of disinformation in elections.

45 See https://www.osce.org/fom/319286 (retrieved 4 March 2019).

46 OsCE Office for Democratic Institutions and Human Rights (ODIHR), Handbook On Media Monitoring for Election Observation Missions, Warsaw, 2012. 